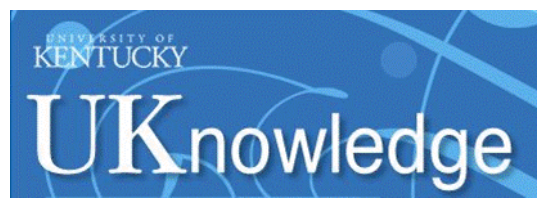

University of Kentucky

UKnowledge

Molecular and Cellular Biochemistry Faculty

Publications

Molecular and Cellular Biochemistry

$5-2014$

\title{
Control of Cellular Motility by Neuropilin-Mediated Physical Interactions
}

\author{
Xiaobo Li \\ University of Kentucky, xiaobo.li1@uky.edu \\ Matthew W. Parker \\ University of Kentucky \\ Craig W. Vander Kooi \\ University of Kentucky, craig.vanderkooi@uky.edu
}

Follow this and additional works at: https://uknowledge.uky.edu/biochem_facpub

Part of the Biochemistry, Biophysics, and Structural Biology Commons

Right click to open a feedback form in a new tab to let us know how this document benefits you.

\section{Repository Citation}

Li, Xiaobo; Parker, Matthew W.; and Vander Kooi, Craig W., "Control of Cellular Motility by NeuropilinMediated Physical Interactions" (2014). Molecular and Cellular Biochemistry Faculty Publications. 69. https://uknowledge.uky.edu/biochem_facpub/69

This Article is brought to you for free and open access by the Molecular and Cellular Biochemistry at UKnowledge. It has been accepted for inclusion in Molecular and Cellular Biochemistry Faculty Publications by an authorized administrator of UKnowledge. For more information, please contact UKnowledge@lsv.uky.edu. 


\section{Control of Cellular Motility by Neuropilin-Mediated Physical Interactions}

\section{Digital Object Identifier (DOI)}

https://doi.org/10.1515/bmc-2013-0035

\section{Notes/Citation Information}

Published in Biomolecular Concepts, v. 5, no. 2, p. 157-166.

(C) 2014 by Walter de Gruyter Berlin/Boston.

This article is distributed under the terms of the Creative Commons Attribution Non-Commercial License, which permits unrestricted non-commercial use, distribution, and reproduction in any medium, provided the original work is properly cited. BY-NC-ND 3.0 


\section{Short Conceptual Overview}

\section{Xiaobo Li, Matthew W. Parker and Craig W. Vander Kooi* \\ Control of cellular motility by neuropilin-mediated physical interactions}

\begin{abstract}
The neuropilin (Nrp) family consists of multifunctional cell surface receptors with critical roles in a number of different cell and tissue types. A core aspect of Nrp function is in ligand-dependent cellular migration, where it controls the multistep process of cellular motility through integration of ligand binding and receptor signaling. At a molecular level, the role of Nrp in migration is intimately connected to the control of adhesive interactions and cytoskeletal reorganization. Here, we review the physiological role of Nrp in cellular adhesion and motility in the cardiovascular and nervous systems. We also discuss the emerging pathological role of Nrp in tumor cell migration and metastasis, providing motivation for continued efforts toward developing Nrp inhibitors.
\end{abstract}

Keywords: cellular motility; neuropilin; receptor signaling; semaphorin; VEGF.

\footnotetext{
${ }^{*}$ Corresponding author: Craig W. Vander Kooi, Department of Molecular and Cellular Biochemistry, Center for Structural Biology, University of Kentucky, 741 South Limestone Avenue, BBSRB B263, Lexington, KY 40536, USA, e-mail: craig.vanderkooi@uky.edu Xiaobo Li and Matthew W. Parker: Department of Molecular and Cellular Biochemistry, Center for Structural Biology, University of Kentucky, 741 South Limestone Avenue, BBSRB B263, Lexington, KY 40536, USA
}

\section{Introduction}

Neuropilins (Nrp) are essential vertebrate cell surface receptors that function to convert extracellular stimuli into directional cellular migration in multiple distinct cell types [reviewed in refs. (1-6)]. Two physiologically important Nrp ligand families include vascular endothelial growth factor (VEGF) and class 3 semaphorins (Sema3) (7-9). Underlying its role in regulating cellular motility and migration is the ability of Nrp to integrate multiple physical mechanisms, including ligand binding, cellular activation, adhesion, and cytoskeletal reorganization.
At a molecular level, Nrp functions through specific physical interactions that include binding to the canonical ligands Sema3 and VEGF (1), other heparin-binding growth factors (10), signaling and adhesive cell surface receptors (1, 11-15), and components of the extracellular matrix (ECM), including glycosaminoglycans (GAGs) $(16,17)$. There are two Nrp genes, Nrp1 and Nrp2, that are conserved in all vertebrates $(8,18)$. Both Nrp homologues share the same subdomain organization and, in humans, are $44 \%$ identical on the amino acid level. Nrp has a large extracellular region composed of two calcium-binding complement binding factors C1s/C1r, Uegf, BMP1 (CUB) domains (a1a2); two coagulation factor V/VIII homology domains (b1b2); a Meprin, A5 antigen, receptor tyrosine phosphatase $\mu$ (MAM) domain (c); a single-pass transmembrane domain (TMD) helix; and a short cytoplasmic tail (Figure 1). The Nrp extracellular domain directly binds to a wide array of molecules that are essential for its versatile function in cellular motility. The TMD has been shown to dimerize and is thought to be important for assembling active signaling complexes $(19,20)$. The Nrp intracellular domain binds to postsynaptic density 95 , disk large, zona occludens-1 (PDZ)-domain containing proteins (21) and is important for regulating interactions with other receptors and the cytoskeleton, thus having an essential role in cellular migration (22-25).

In particular, the extracellular b1b2 domains serve a central role in specific binding and competition for a large number of ligands (1, 26-28). Thus, for example, it has been demonstrated that the VEGF-A C-terminus binds to a specific binding pocket formed by the coagulation factor loops of the b1 domain of Nrp1 (29). Sema3 engagement is more complex and involves both the Nrp a1 and b1 domains $(26,30)$. Current models indicate that the Nrp a1 domain binds the Sema domain of different Sema3 family members, controlling specificity, while the Nrp b1 domain binds to the Sema3 C-terminal basic domain, controlling high-affinity binding (30-35). This model is affected by the recent discovery that the a2 domain of Nrp integrally interacts with b1 and b2 domains forming a stable core (36). Thus, domain deletion experiments, which generally 


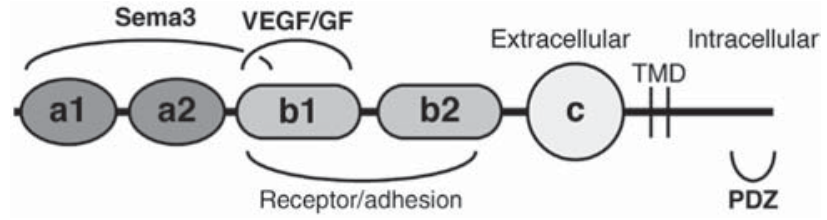

Figure 1 Nrp structure. Nrps contain a large, modular extracellular region that facilitates binding to multiple ligand families in both a competitive and non-competitive fashion. Ligand binding is coupled to intracellular signaling through PDZ-domain-containing adaptor proteins that bind the SEA motif of the Nrp cytoplasmic domain.

delete $\mathrm{a} 1 \mathrm{a} 2$ or $\mathrm{b} 1 \mathrm{~b} 2$ in tandem, may have more complex interpretations. A recently published structure of Sema3A/ PlexinA2/Nrp1 complex has begun to elucidate the molecular details of the Sema3 signaling machinery. This structure revealed that the Nrp1 a1 domain cross-braces the Sema domains of Sema3A and PlexinA2, assembling them to form a dimer of heterotrimers critical for the activation of signaling $(37,38)$.

Regulatory mechanisms controlling Nrp ligand binding and the coupling of different domains are an active area of research. Post-translational modification of Nrp ligands critically regulates their Nrp binding and activity. Alternative splicing and proteolytic processing of the VEGF family can dramatically alter Nrp binding and ligand activity $(9,39-43)$. Proteolytic processing of the C-terminal basic domain of Sema3 family members by furin critically regulates binding to the Nrp b1 domain $(44,45)$ and chemotactic activity (46-48). Despite these data, the importance of furin processing in physiological Sema3 signaling has remained an open question. The recent report that Kallmann's syndrome, a serious genetic disease resulting from defects in axon guidance, can be caused by mutations in a furin-cleavage site in the C-terminal domain of Sema3A (49) argues strongly for the physiological importance of furin processing and Nrp engagement.

Nrp1 was originally identified as a cell adhesion molecule $(50,51)$. It was shown that expression of Nrp1 conferred adhesiveness to fibroblasts through heterophilic interaction with a protease-sensitive molecule (51). The adhesive function of Nrp was later mapped to the b1b2 coagulation factor domains (52), and subsequent studies demonstrated that the identified region within domain b2 was also responsible for GAG binding (53). In addition to GAG-dependent adhesion, Nrp can couple with other cell surface receptors to modulate cellular adhesion. Specifically, Nrp has been demonstrated to modulate integrindependent cellular motility, where the receptors appear to couple through both extracellular and intracellular mechanisms to regulate VEGF-dependent endothelial cell migration in angiogenesis (54).

\section{Nrp-dependent VEGF signaling}

VEGF-dependent angiogenesis occurs within the context of a ligand/receptor holocomplex that includes VEGF, Nrp, and the receptor tyrosine kinase, VEGFR (Figure 2). As co-receptors in VEGF-dependent angiogenesis, Nrps function by directly binding ligand and regulating VEGFR signaling and cellular activation [reviewed in refs. $(1,55-$ 58)]. Nrp1 and Nrp2 transduce signals for different VEGF family members. For instance, Nrp1 signaling is critical for VEGF-A-dependent angiogenesis $(9,59)$ and Nrp2 for VEGF-C-dependent lymphangiogenesis $(43,60)$.

Genetic studies have demonstrated the importance of Nrp1 within the VEGF-A/VEGFR-2/Nrp1 signaling holocomplex. Knockout of Nrp1 in mice results in embryonic lethality owing to widely distributed defects in vascular patterning (61-63) and overexpression of Nrp1, which is also embryonic lethal, causing hypervascularization within the cardiovascular system (64). The vascular phenotype of the Nrp knockout is similar to that of VEGF-A heterozygous mice $(65,66)$ and VEGFR-2 null mutant mice (67), although reduced in severity. Interestingly,

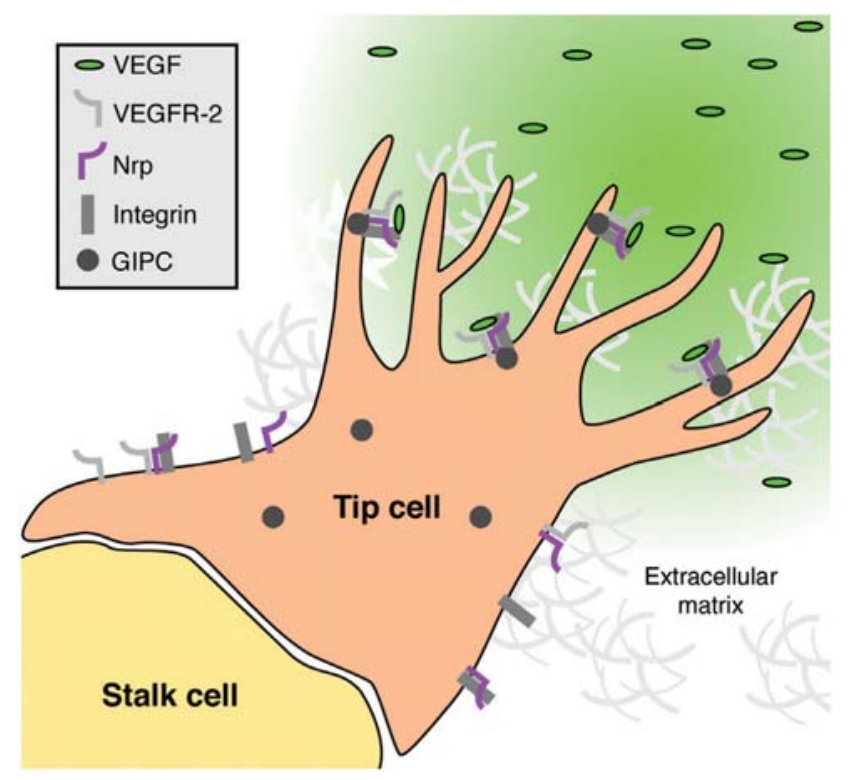

Figure 2 Nrp critically modulates endothelial tip cell function. Nrp is highly expressed in endothelial tip cells where it promotes branching and directional migration in response to VEGF. In tip cells, Nrp serves several essential functions, including ligand binding, holocomplex formation, integrin coupling, and recycling of co-receptors and components of focal adhesions. 
a detailed study of the Nrp1 knockout mouse demonstrated that endothelial cell migration, but not proliferation, is defective in the absence of Nrp1 (68). Indeed, Nrp1 knockdown in human umbilical vein endothelial cells (HUVECs) causes impaired F-actin reorganization and focal adhesion distribution during endothelial cell attachment to the ECM (69). A number of studies have also described an essential role for Nrp in endothelial tip cell function (70) (Figure 2). Nrp1 is highly expressed in endothelial tip cell filopodia, and VEGF-A stimulates filopodia extension from the tip cells resulting in branching $(71,72)$. The same principle has been observed in VEGFC-dependent lymphangiogenesis where Nrp2 is highly expressed in lymphatic tip cells (73) as well as in tip cell filopodia, and selectively modulates VEGFC/VEGFR3mediated tip cell extension but not cellular proliferation or survival (74).

The Nrp intracellular domain was initially considered dispensable for its function in angiogenesis. However, it is now understood that the Nrp intracellular domain functions to couple ligand binding to downstream mediators of angiogenesis. Deletion of the intracellular domain leads to impaired arteriogenesis and abnormal retinal artery and vein crossover $(75,76)$. Additionally, a chimeric receptor, composed of the extracellular domain of epidermal growth factor receptor (EGFR) fused to the TMD and cytoplasmic domains of Nrp1, was found to mediate EGF-induced HUVEC migration but not proliferation (77). The intracellular adaptor protein RGS-GAIPinteracting protein $\mathrm{C}$-terminus (GIPC) has been shown to bind to the intracellular domain of both $\operatorname{Nrp}(21)$ and integrin (78). These data suggest a direct mechanism for Nrp-dependent modulation of integrin function through coupling of intracellular domains. Indeed, $\alpha_{5} \beta_{1}$ integrin, which binds GIPC, was shown to mediate endothelial cell spreading on fibronectin through a mechanism dependent on the Nrp intracellular domain and GIPC (24). Furthermore, it was recently demonstrated that the Nrp intracellular domain directly binds and traffics protein components of focal adhesions, functioning to promote rapid focal adhesion turnover and cellular migration (79). Similarly, the Nrp intracellular domain has also been found to be essential for ligand-specific receptor localization and trafficking. Binding of VEGF$\mathrm{A}_{165}$ to Nrp1 induces VEGF-A/VEGFR-2/Nrp1 complex formation, receptor internalization, and recycling back to the membrane (12). Nrp1 was found to play a specific role in recycling as the binding of VEGF- $\mathrm{A}_{165} \mathrm{~b}$, an alternative VEGF-A spliceform that does not bind Nrp, results in VEGFR-2 degradation through an alternative recycling pathway (80).

\section{Nrp-dependent Sema3 signaling}

Nrp was initially discovered in Xenopus and was shown to be involved in mediating neuronal wiring through cellcell adhesion $(50,81)$. The function of Nrps in the nervous system is multifaceted and extends beyond their adhesive properties to regulation of both axon guidance and cellular migration. Nrp functions as an important co-receptor for the Sema3 family (Sema3A-G) of axon guidance molecules, directly physically coupling with plexin receptors to mediate signaling and cellular activation [extensively reviewed in refs. $(1,5,8,13,82,83)$ ] (Figure 3).

Nrp1 and Nrp2 have a unique Sema3 binding specificity and perform distinct biological functions in the nervous system $(84,85)$. Nrp1 null mice show defects in neuronal axon pathfinding in both the central and peripheral nervous systems $(61,62,86)$. Additionally, Nrp1 knockdown impairs the migration and invasion of cranial neural crest cells into the branchial arches, leading to the failed development of the peripheral architecture (87). Nrp2 null mice $(88,89)$ have impaired spinal sensory axon projection and hippocampal mossy fiber axon projection (90), along with abnormal sensory neuronal axon innervation and fasciculation in the olfactory bulb (91). Specific signaling is accomplished by tissue-specific expression and action of different Sema3, plexin, and Nrp family members $(30,88,89)$. Additionally, there are exceptions to the canonical Sema3/Nrp signaling, with Sema4A reported to have Nrp-dependent function in the immune system (92) and Sema3E having Nrp-independent function (93).

Physically, signaling through Sema3 involves interaction in extracellular, membrane, and intracellular regions of the cell that control adhesive interactions and cytoskeletal dynamics (94) (Figure 3). The intracellular region of plexins contains a GTPase-activating protein domain (GAP) and directly binds to Rho and Ras family GTPases, including, but not limited to, Rnd1, RhoD, R-Ras, M-Ras, and Rap1. Rnd1 binding initiates Sema3A-induced actin depolymerization, leading to sensory neuron growth cone turning and collapse. Conversely, RhoD antagonizes Rnd1 and inhibits Sema3 function (95). Plexin-mediated regulation of both R-Ras and M-Ras is critical for semaphorinmediated signaling in both neuronal and vascular cells (96-98). While multiple GTPases interact with the intracellular region of plexin family members, recent work demonstrating the dimerization-dependent interaction of plexin with Rap1 indicates that multiple physical interaction mechanisms distinguish the different families (99). Additionally, plexins bind to molecule interacting with CasL (MICALs), an oxidoreductase that functions as an 


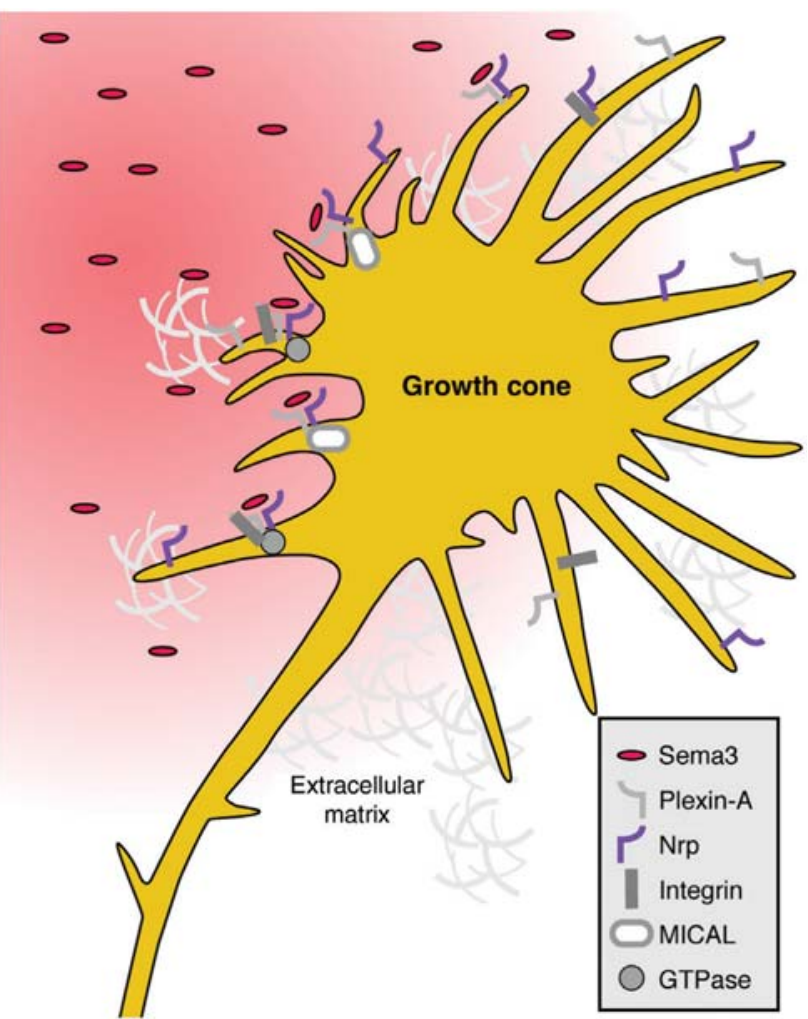

Figure 3 Nrp critically modulates neuronal growth cone function. Nrp is expressed in the axonal growth cone of migrating neurons where it couples with plexin receptors in responding to the guidance cue Sema3. Nrp functions by coupling high-affinity ligand binding to plexin-dependent cytoskeletal rearrangement through different GTPases and MICAL.

F-actin disassembly factor (100). The cellular response to Sema3 stimulation also depends on the intracellular environment. For example, the availability of the second messenger cGMP has been demonstrated to switch Sema3dependent repulsive cues into an attractive response in neurons (101). Similar to the discussion above, the coupling of Nrp-dependent function to integrin interactions and signaling is an important aspect of the integrated cellular and physiological response to Sema3 signaling.

Nrp function as a versatile co-receptor depends on its ability to integrate multiple extracellular cues that can result in either stimulation or inhibition of the cytoskeletal dynamics $(1,102,103)$. For example, VEGF-A stimulates axon outgrowth $(104,105)$, whereas Sema3F blocks endothelial cell migration (106). Thus, Nrp function allows cross-talk between different ligand families in different tissues and provides exquisite control of cellular migration $(107,108)$. The nature and regulation of this cross-talk involves competitive binding of the two ligands to the b1 domain of Nrp and is dependent on the furin processing of Sema3 $(26,44,109,110)$. While the binding of the two ligands to Nrp appears to be mutually exclusive in most cases, it is theoretically possible to support some level of Sema3 binding either to only the Nrp a1 domain or, given recent data indicating a bivalent binding mode for the Sema3 C-terminal domain with the Nrp b1 domain, partial engagement in the absence of processing (111). The unique ability of Sema3 family members to inhibit cytoskeletal dynamics is seen in both physiological and pathological settings. Indeed, Sema3A has been shown to disrupt the actin cytoskeleton of breast cancer cells, thus decreasing their migration and invasion (112).

\section{Nrp in tumor metastasis}

In addition to the important role of Nrp in development and homeostasis, aberrant Nrp pathway activation has been observed in diverse tumors, including those of the prostate, lung, gastrointestinal tract, numerous additional organs, and even hematopoietic tumors $(113,114)$. Importantly, both Nrp1 and Nrp2 expression contribute to the invasiveness and metastatic potential of these tumors. For example, Nrp1 functions in an autocrine pathway to promote colon carcinoma migration, lymph node metastasis, and tumor cell survival (115). As an additional example, Nrp2 expression has been reported in gastrointestinal cancer cells but not in the normal surrounding mucosa and Nrp2 knockdown leads to decreased migration and invasion in vitro (116). Nrp2 expression is also observed in salivary adenoid cystic carcinoma and is highly correlated with microvessel density, tumor size, invasion, and metastasis (117). A number of factors make Nrp2 a particularly promising target for therapeutic intervention (Figure 4). Specifically, Nrp2 expression is seen in a significant number of tumors where it contributes to tumor metastasis and progression. Indeed, use of an Nrp2 monoclonal antibody has been reported to decrease tumor metastasis $(73,117)$. Additionally, Nrp2 knockout does not result in embryonic lethality, indicating that therapeutic inhibition of Nrp2 function may be well tolerated in vivo. Finally, Nrp2 functions in controlling pathological lymphangiogenesis, where it contributes to tumor metastasis through both direct and indirect means (114).

Pathological Nrp activation can result from either Nrp overexpression or from the deregulation of ligand activity, such as overactive VEGF or a loss of Sema3 signaling (118). Indeed, the relative level of the opposing Sema3 and VEGF signals has been shown to regulate Nrp1-dependent cancer cell migration (119). The connection to aberrant Nrp function extends beyond stimulation by ligands. 


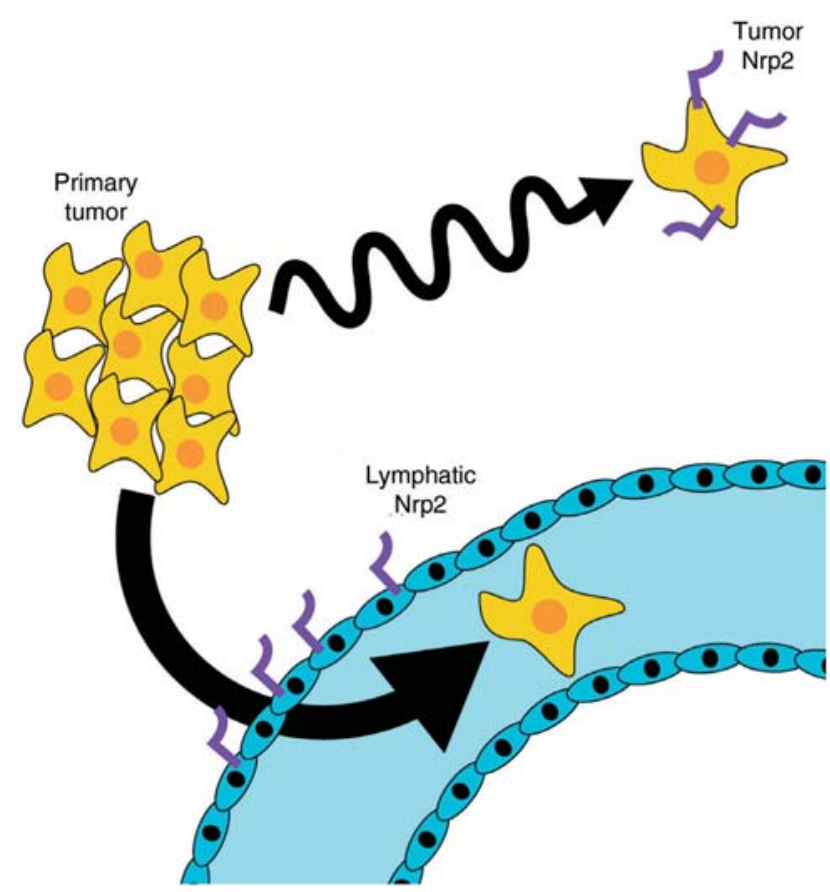

Figure $4 \mathrm{Nrp} 2$ is an important therapeutic target in cancer. Nrp2 is highly expressed in a number of different cancers where it promotes cellular migration, invasion, and metastasis. Additionally, lymphatic vessel expressing Nrp2 provide a route for tumor invasion and local metastasis.

Coupling between Nrp and integrin was first recognized under pathological conditions. Nrp1 is highly expressed in pancreatic ductal adenocarcinomas where it associates with $\beta 1$ integrin to promote cellular adhesion and invasion (120). An interaction between Nrp2 and $\alpha_{6} \beta_{1}$ integrin was demonstrated and was shown to regulate integrin interaction with the cytoskeleton and focal adhesion formation on laminin in breast cancer cells (121). Likewise, Nrp2 has also been demonstrated to bind $\alpha_{5}$ integrin and mediate tumor cell extravasation, vascular adhesion, and metastasis (122).

Given their pathological roles, it is clear that Nrp receptors represent a promising therapeutic target. Initial attempts at inhibition focused on the production of a series of monoclonal antibodies against both Nrp1 and Nrp2. Intriguingly, phase I clinical trial results for MNRP1685A, a Nrp1 monoclonal antibody, showed unexpected platelet activation and thrombocytopenia (123). Other inhibitory modalities have been reported, including peptides and small molecules (124-126). Challenges with these classes of inhibitors include limited potency and selectivity. However, recent findings suggest that this is not an inherent limitation and continued development of diverse inhibitory modalities should be pursued $(111,127)$. Additionally, labeled Nrp-binding molecules could potentially be useful for diagnostic purposes. Also, emerging dataindicate that Nrp/integrin interactions function as important autocrine tumor initiation and survival factors and thus inhibition may have additional benefit $(3,120,128,129)$. Future biochemical and structural studies will be important to guide inhibitor design.

\section{Summary}

Nrps function as critical cell surface receptors in the physiological and pathological control of cellular motility and migration. Initially, Nrp was described as an adhesive receptor in the nervous system and has been additionally shown to possess critical roles in the cardiovascular system, immune system, and beyond. Nrp functions as a versatile co-receptor in these processes by binding to multiple ligands and facilitating molecular cross-talk between the different ligand families. Understanding the nature of Nrp activation and receptor coupling is critical for understanding its function.

Continued work is needed to define the physiological role of the multiple Nrp ligand and co-receptor families of proteins, and to understand how these protein families physically engage Nrp. The basis for ligand binding has been a source of intensive study, and fundamental insights about the importance of a C-terminal arginine residue have proven fruitful $(29,53,130-132)$. However, with the identification of a host of potential Nrp ligand families, continued work is needed to define the physiological role of Nrp signaling by these ligands.

In VEGF signaling, where both VEGFR and Nrp receptors are required, Nrp is intimately connected to the ability of endothelial cells to respond to ligand concentration gradients leading to directional migration. Similarly, Nrp function in the axon growth cone allows directional migration in response to Sema3 concentration gradients. In these processes, Nrp functions in ligand-dependent control of cellular motility and migration. The downstream functions of Nrps involve both direct physical coupling with integrins and regulation of cytoskeletal dynamics. Finally, Nrp function plays a critical role not only in physiological processes but also in pathological cellular migration. Aberrant activation of both Nrp1 and Nrp2 are associated with tumor aggressiveness and metastasis.

Finally, the basis for receptor/co-receptor coupling remains an important area for future research. In particular, the nature of Nrp binding to signaling receptors in both the presence and absence of ligand remains unclear. The architecture and differential specific coupling to VEGFR 
family members, plexins, and other receptors remains to be determined. These insights will be particularly important in understanding additional fundamental aspects of Nrp function. Additionally, while current therapeutic strategies focus on blocking ligand binding, inhibition of receptor coupling may, in fact, prove superior to traditional inhibition strategies (133).

\section{References}

1. Parker MW, Guo HF, Li X, Linkugel AD, Vander Kooi CW. Function of members of the neuropilin family as essential pleiotropic cell surface receptors. Biochemistry 2012; 51: 9437-46.

2. Casazza A, Fazzari P, Tamagnone L. Semaphorin signals in cell adhesion and cell migration: functional role and molecular mechanisms. Adv Exp Med Biol 2007; 600: 90-108.

3. Perrot-Applanat $M$, Di Benedetto $M$. Autocrine functions of VEGF in breast tumor cells: adhesion, survival, migration and. invasion. Cell Adh Migr 2012; 6: 547-53.

4. Mendes-da-Cruz DA, Stimamiglio MA, Munoz JJ, Alfaro D, Terra-Granado E, Garcia-Ceca J, Alonso-Colmenar LM, Savino W, Zapata AG. Developing T-cell migration: role of semaphorins and ephrins. FASEB J 2012; 26: 4390-9.

5. Bagri A, Tessier-Lavigne M. Neuropilins as Semaphorin receptors: in vivo functions in neuronal cell migration and axon guidance. Adv Exp Med Biol 2002; 515: 13-31.

6. Cebe-Suarez S, Zehnder-Fjallman A, Ballmer-Hofer K. The role of VEGF receptors in angiogenesis; complex partnerships. Cell Mol Life Sci 2006; 63: 601-15.

7. He Z, Tessier-Lavigne M. Neuropilin is a receptor for the axonal chemorepellent Semaphorin III. Cell 1997; 90: 739-51.

8. Kolodkin AL, Levengood DV, Rowe EG, Tai YT, Giger RJ, Ginty DD. Neuropilin is a semaphorin III receptor. Cell 1997; 90: 753-62.

9. Soker S, Takashima S, Miao HQ, Neufeld G, Klagsbrun M. Neuropilin-1 is expressed by endothelial and tumor cells as an isoform-specific receptor for vascular endothelial growth factor. Cell 1998; 92: 735-45.

10. West DC, Rees CG, Duchesne L, Patey SJ, Terry CJ, Turnbull JE, Delehedde M, Heegaard CW, Allain F, Vanpouille C, Ron D, Fernig DG. Interactions of multiple heparin binding growth factors with neuropilin-1 and potentiation of the activity of fibroblast growth factor-2. J Biol Chem 2005; 280: 13457-64.

11. Koch S, Claesson-Welsh L. Signal transduction by vascular endothelial growth factor receptors. Cold Spring Harb Perspect Med 2012; 2: a006502.

12. Berger P, Ballmer-Hofer K. The reception and the party after: how vascular endothelial growth factor receptor 2 explores cytoplasmic space. Swiss Med Wkly 2011; 141: w13318.

13. Hota PK, Buck M. Plexin structures are coming: opportunities for multilevel investigations of semaphorin guidance receptors, their cell signaling mechanisms, and functions. Cell Mol Life Sci 2012; 69: 3765-805.

14. Schwarz Q, Ruhrberg C. Neuropilin, you gotta let me know: should I stay or should I go? Cell Adh Migr 2010; 4: 61-6.

15. Goel HL, Mercurio AM. Enhancing integrin function by VEGF/ neuropilin signaling: implications for tumor biology. Cell Adh Migr 2012; 6: 554-60.
Acknowledgments: We thank Mr. Hou-Fu Guo for helpful discussions. This work was supported by National Institutes of Health grant R01GM094155. The authors declare no conflicts of interest.

Received November 22, 2013; accepted February 3, 2014

16. Fuh G, Garcia KC, de Vos AM. The interaction of neuropilin-1 with vascular endothelial growth factor and its receptor flt-1. J Biol Chem 2000; 275: 26690-5.

17. de Wit J, Verhaagen J. Proteoglycans as modulators of axon guidance cue function. Adv Exp Med Biol 2007; 600: 73-89.

18. Takagi S, Hirata T, Agata K, Mochii M, Eguchi G, Fujisawa H. The A5 antigen, a candidate for the neuronal recognition molecule, has homologies to complement components and coagulation factors. Neuron 1991; 7: 295-307.

19. Roth L, Nasarre C, Dirrig-Grosch S, Aunis D, Cremel G, Hubert P, Bagnard D. Transmembrane domain interactions control biological functions of neuropilin-1. Mol Biol Cell 2008; 19: 646-54.

20. Nasarre C, Roth M, Jacob L, Roth L, Koncina E, Thien A, Labourdette G, Poulet P, Hubert P, Crémel G, Roussel G, Aunis D, Bagnard D. Peptide-based interference of the transmembrane domain of neuropilin-1 inhibits glioma growth in vivo. Oncogene 2010; 29: 2381-92.

21. Cai H, Reed RR. Cloning and characterization of neuropilin1-interacting protein: a PSD-95/Dlg/ZO-1 domain-containing protein that interacts with the cytoplasmic domain of neuropilin-1. J Neurosci 1999; 19: 6519-27.

22. Wang L, Mukhopadhyay D, Xu X. C terminus of RGS-GAIPinteracting protein conveys neuropilin-1-mediated signaling during angiogenesis. FASEB J 2006; 20: 1513-5.

23. Prahst C, Heroult M, Lanahan AA, Uziel N, Kessler O, Shraga-Heled N, Simons M, Neufeld G, Augustin HG. Neuropilin1-VEGFR-2 complexing requires the PDZ-binding domain of neuropilin-1. J Biol Chem 2008; 283: 25110-4.

24. Valdembri D, Caswell PT, Anderson KI, Schwarz JP, Konig I, Astanina E, Caccavari F, Norman JC, Humphries MJ, Bussolino F, Serini G. Neuropilin-1/GIPC1 signaling regulates $\alpha_{5} \beta_{1}$ integrin traffic and function in endothelial cells. PLoS Biol 2009; 7: e25.

25. Hillman RT, Feng BY, Ni J, Woo WM, Milenkovic L, Hayden Gephart MG, Teruel MN, Oro AE, Chen JK, Scott MP. Neuropilins are positive regulators of Hedgehog signal transduction. Genes Dev 2011; 25: 2333-46.

26. Gu C, Limberg BJ, Whitaker GB, Perman B, Leahy DJ, Rosenbaum JS, Ginty DD, Kolodkin AL. Characterization of neuropilin-1 structural features that confer binding to semaphorin $3 \mathrm{~A}$ and vascular endothelial growth factor 165 . J Biol Chem 2002; 277: 18069-76.

27. Mamluk R, Gechtman Z, Kutcher ME, Gasiunas N, Gallagher J, Klagsbrun M. Neuropilin-1 binds vascular endothelial growth factor 165, placenta growth factor-2, and heparin via its b1b2 domain. J Biol Chem 2002; 277: 24818-25. 
28. Parker MW, Xu P, Guo HF, Vander Kooi CW. Mechanism of selective VEGF-A binding by neuropilin-1 reveals a basis for specific ligand inhibition. PLoS One 2012; 7: e49177.

29. Parker MW, Xu P, Li X, Vander Kooi CW. Structural basis for selective vascular endothelial growth factor-A (VEGF-A) binding to neuropilin-1. J Biol Chem 2012; 287: 11082-9.

30. Chen H, He Z, Bagri A, Tessier-Lavigne M. Semaphorinneuropilin interactions underlying sympathetic axon responses to class III semaphorins. Neuron 1998; 21: 1283-90.

31. Koppel AM, Feiner L, Kobayashi H, Raper JA. A 70 amino acid region within the semaphorin domain activates specific cellular response of semaphorin family members. Neuron 19: 531-7.

32. Giger RJ, Urquhart ER, Gillespie SK, Levengood DV, Ginty DD, Kolodkin AL. Neuropilin-2 is a receptor for semaphorin IV: insight into the structural basis of receptor function and specificity. Neuron 1998; 21: 1079-92.

33. Nakamura F, Tanaka M, Takahashi T, Kalb RG, Strittmatter SM. Neuropilin-1 extracellular domains mediate semaphorin D/ III-induced growth cone collapse. Neuron 1998; 21: 1093-100.

34. Renzi MJ, Feiner L, Koppel AM, Raper JA. A dominant negative receptor for specific secreted semaphorins is generated by deleting an extracellular domain from neuropilin-1. J Neurosci 1999; 19: 7870-80.

35. Merte J, Wang Q, Vander Kooi CW, Sarsfield S, Leahy DJ, Kolodkin AL, Ginty DD. A forward genetic screen in mice identifies Sema3A(K108N), which binds to neuropilin-1 but cannot signal. J Neurosci 2010; 30: 5767-75.

36. Appleton BA, Wu P, Maloney J, Yin J, Liang WC, Stawicki S, Mortara K, Bowman KK, Elliott JM, Desmarais W, Bazan JF, Bagri A, Tessier-Lavigne M, Koch AW, Wu Y, Watts RJ, Wiesmann C. Structural studies of neuropilin/antibody complexes provide insights into semaphorin and VEGF binding. EMBO J 2007; 26: 4902-12.

37. Janssen BJ, Malinauskas T, Weir GA, Cader MZ, Siebold C, Jones EY. Neuropilins lock secreted semaphorins onto plexins in a ternary signaling complex. Nat Struct Mol Biol 2012; 19: 1293-9.

38. Siebold C, Jones EY. Structural insights into semaphorins and. their receptors. Semin Cell Dev Biol 2013; 24: 139-45.

39. Park JE, Keller GA, Ferrara N. The vascular endothelial growth factor (VEGF) isoforms: differential deposition into the subepithelial extracellular matrix and bioactivity of extracellular matrix-bound VEGF. Mol Biol Cell 1993; 4: 1317-26.

40. Pan Q, Chathery Y, Wu Y, Rathore N, Tong RK, Peale F, Bagri A, Tessier-Lavigne M, Koch AW, Watts RJ. Neuropilin-1 binds to VEGF121 and regulates endothelial cell migration and sprouting. J Biol Chem 2007; 282: 24049-56.

41. Vintonenko N, Pelaez-Garavito I, Buteau-Lozano H, Toullec A, Lidereau R, Perret GY, Bieche I, Perrot-Applanat M. Overexpression of VEGF189 in breast cancer cells induces apoptosis via NRP1 under stress conditions. Cell Adh Migr 2011; 5: 332-43.

42. Ng YS, Rohan R, Sunday ME, Demello DE, D’Amore PA. Differential expression of VEGF isoforms in mouse during development and in the adult. Dev Dyn 2001; 220: 112-21.

43. Karpanen T, Heckman CA, Keskitalo S, Jeltsch M, Ollila H, Neufeld G, Tamagnone L, Alitalo K. Functional interaction of VEGF-C and VEGF-D with neuropilin receptors. FASEB J 2006; 20: 1462-72.

44. Parker MW, Hellman LM, Xu P, Fried MG, Vander Kooi CW. Furin processing of semaphorin $3 F$ determines its anti-angiogenic activity by regulating direct binding and competition for neuropilin. Biochemistry 2010; 49: 4068-75.
45. Parker MW, Linkugel AD, Vander Kooi CW. Effect of C-terminal sequence on competitive semaphorin binding to neuropilin-1. J Mol Biol 2013; 425: 4405-14.

46. Adams RH, Lohrum M, Klostermann A, Betz H, Puschel AW. The chemorepulsive activity of secreted semaphorins is regulated. by furin-dependent proteolytic processing. EMBO J 1997; 16: 6077-86.

47. Varshavsky A, Kessler O, Abramovitch S, Kigel B, Zaffryar S, Akiri G, Neufeld G. Semaphorin-3B is an angiogenesis inhibitor that is inactivated by furin-like pro-protein convertases. Cancer Res 2008; 68: 6922-31.

48. Casazza A, Kigel B, Maione F, Capparuccia L, Kessler O, Giraudo E, Mazzone M, Neufeld G, Tamagnone L. Tumour growth inhibition and anti-metastatic activity of a mutated furin-resistant Semaphorin 3E isoform. EMBO Mol Med 2012; 4: 234-50.

49. Hanchate NK, Giacobini P, Lhuillier P, Parkash J, Espy C, Fouveaut C, Leroy C, Baron S, Campagne C, Vanacker C, Collier F, Cruaud C, Meyer V, García-Piñero A, Dewailly D, Cortet-Rudelli C, Gersak K, Metz C, Chabrier G, Pugeat M, Young J, Hardelin JP, Prevot V, Dodé C. SEMA3A, a gene involved in axonal pathfinding, is mutated in patients with Kallmann syndrome. PLoS Genet 2012; 8: e1002896.

50. Takagi S, Tsuji T, Amagai T, Takamatsu T, Fujisawa H. Specific cell surface labels in the visual centers of Xenopus laevis tadpole identified using monoclonal antibodies. Dev Biol 1987; 122: 90-100.

51. Takagi S, Kasuya Y, Shimizu M, Matsuura T, Tsuboi M, Kawakami A, Fujisawa H. Expression of a cell adhesion molecule, neuropilin, in the developing chick nervous system. Dev Biol 1995; 170: 207-22.

52. Shimizu M, Murakami Y, Suto F, Fujisawa H. Determination of cell adhesion sites of neuropilin-1. J Cell Biol 2000; 148: 1283-93.

53. Vander Kooi CW, Jusino MA, Perman B, Neau DB, Bellamy $H D$, Leahy DJ. Structural basis for ligand and heparin binding to neuropilin B domains. Proc Natl Acad Sci USA 2007; 104: 6152-7.

54. Bussolino F, Caccavari F, Valdembri D, Serini G. Angiogenesis: a balancing act between integrin activation and inhibition? Eur Cytokine Netw 2009; 20: 191-6.

55. Pellet-Many C, Frankel P, Jia H, Zachary I. Neuropilins: structure, function and role in disease. Biochem J 2008; 411: 211-26.

56. Zachary IC, Frankel P, Evans IM, Pellet-Many C. The role of neuropilins in cell signalling. Biochem Soc Trans 2009; 37: 1171-8.

57. Staton CA, Kumar I, Reed MW, Brown NJ. Neuropilins in physiological and pathological angiogenesis. J Pathol 2007; 212: 237-48.

58. Neufeld G, Cohen T, Shraga N, Lange T, Kessler O, Herzog Y. The neuropilins: multifunctional semaphorin and VEGF receptors that modulate axon guidance and angiogenesis. Trends Cardiovasc Med 2002; 12: 13-9.

59. Lee P, Goishi K, Davidson AJ, Mannix R, Zon L, Klagsbrun M. Neuropilin-1 is required for vascular development and is a mediator of VEGF-dependent angiogenesis in zebrafish. Proc Natl Acad Sci USA 2002; 99: 10470-5.

60. Yuan L, Moyon D, Pardanaud L, Breant C, Karkkainen MJ, Alitalo K, Eichmann A. Abnormal lymphatic vessel development in neuropilin 2 mutant mice. Development 2002; 129: 4797-806. 
61. Kawasaki T, Kitsukawa T, Bekku Y, Matsuda Y, Sanbo M, Yagi T, Fujisawa H. A requirement for neuropilin-1 in embryonic vessel formation. Development 1999; 126: 4895-902.

62. Kitsukawa T, Shimizu M, Sanbo M, Hirata T, Taniguchi M, Bekku Y, Yagi T, Fujisawa H. Neuropilin-semaphorin III/Dmediated chemorepulsive signals play a crucial role in peripheral nerve projection in mice. Neuron 1997; 19: 995-1005.

63. Takashima S, Kitakaze M, Asakura M, Asanuma H, Sanada S, Tashiro F, Niwa H, Miyazaki Ji J, Hirota S, Kitamura Y, Kitsukawa T, Fujisawa H, Klagsbrun M, Hori M. Targeting of both mouse neuropilin-1 and neuropilin-2 genes severely impairs developmental yolk sac and embryonic angiogenesis. Proc Natl Acad Sci USA 2002; 99: 3657-62.

64. Kitsukawa T, Shimono A, Kawakami A, Kondoh H, Fujisawa H. Overexpression of a membrane protein, neuropilin, in chimeric mice causes anomalies in the cardiovascular system, nervous system and limbs. Development 1995; 121: 4309-18.

65. Carmeliet P, Ferreira V, Breier G, Pollefeyt S, Kieckens L, Gertsenstein M, Fahrig M, Vandenhoeck A, Harpal K, Eberhardt C, Declercq C, Pawling J, Moons L, Collen D, Risau W, Nagy A. Abnormal blood vessel development and lethality in embryos lacking a single VEGF allele. Nature 1996; 380: 435-9.

66. Ferrara N, Carver-Moore K, Chen H, Dowd M, Lu L, O'Shea KS, Powell-Braxton L, Hillan KJ, Moore MW. Heterozygous embryonic lethality induced by targeted inactivation of the VEGF gene. Nature 1996; 380: 439-42.

67. Shalaby F, Rossant J, Yamaguchi TP, Gertsenstein M, Wu XF, Breitman ML, Schuh AC. Failure of blood-island formation and vasculogenesis in Flk-1-deficient mice. Nature 1995; 376: 62-6.

68. Jones EA, Yuan L, Breant C, Watts RJ, Eichmann A. Separating genetic and hemodynamic defects in neuropilin 1 knockout embryos. Development 2008; 135: 2479-88.

69. Murga M, Fernandez-Capetillo O, Tosato G. Neuropilin-1 regulates attachment in human endothelial cells independently of vascular endothelial growth factor receptor-2. Blood 2005; 105: 1992-9.

70. Gerhardt H, Ruhrberg C, Abramsson A, Fujisawa H, Shima D, Betsholtz C. Neuropilin-1 is required for endothelial tip cell guidance in the developing central nervous system. Dev Dyn 2004; 231: 503-9.

71. Gerhardt H, Golding M, Fruttiger M, Ruhrberg C, Lundkvist A, Abramsson A, Jeltsch M, Mitchell C, Alitalo K, Shima D, Betsholtz C. VEGF guides angiogenic sprouting utilizing endothelial tip cell filopodia. J Cell Biol 2003; 161: 1163-77.

72. Fantin A, Vieira JM, Plein A, Denti L, Fruttiger M, Pollard JW, Ruhrberg C. NRP1 acts cell autonomously in endothelium to promote tip cell function during sprouting angiogenesis. Blood 2013; 121: 2352-62.

73. Caunt M, Mak J, Liang WC, Stawicki S, Pan Q, Tong RK, Kowalski J, Ho C, Reslan HB, Ross J, Berry L, Kasman I, Zlot C, Cheng Z, Le Couter J, Filvaroff EH, Plowman G, Peale F, French D, Carano R, Koch AW, Wu Y, Watts RJ, Tessier-Lavigne M, Bagri A. Blocking neuropilin-2 function inhibits tumor cell metastasis. Cancer Cell 2008; 13: 331-42.

74. Xu Y, Yuan L, Mak J, Pardanaud L, Caunt M, Kasman I, Larrivée B, Del Toro R, Suchting S, Medvinsky A, Silva J, Yang J, Thomas JL, Koch AW, Alitalo K, Eichmann A, Bagri A. Neuropilin-2 mediates VEGF-C-induced lymphatic sprouting together with VEGFR3. J Cell Biol 2010; 188: 115-30.
75. Lanahan A, Zhang X, Fantin A, Zhuang Z, Rivera-Molina F, Speichinger K, Prahst C, Zhang J, Wang Y, Davis G, Toomre D, Ruhrberg C, Simons M. The neuropilin 1 cytoplasmic domain is required for VEGF-A-dependent arteriogenesis. Dev Cell 2013; 25: 156-68.

76. Fantin A, Schwarz Q, Davidson K, Normando EM, Denti L, Ruhrberg C. The cytoplasmic domain of neuropilin 1 is dispensable for angiogenesis, but promotes the spatial separation of retinal arteries and veins. Development 2011; 138: 4185-91.

77. Wang L, Zeng H, Wang P, Soker S, Mukhopadhyay D. Neuropilin1-mediated vascular permeability factor/vascular endothelial growth factor-dependent endothelial cell migration. J Biol Chem 2003; 278: 48848-60.

78. El Mourabit H, Poinat P, Koster J, Sondermann H, Wixler V, Wegener E, Laplantine E, Geerts D, Georges-Labouesse E, Sonnenberg A, Aumailley M. The PDZ domain of TIP-2/GIPC interacts with the $C$-terminus of the integrin $\alpha 5$ and $\alpha 6$ subunits. Matrix Biol 2002; 21: 207-14.

79. Seerapu HR, Borthakur S, Kong N, Agrawal S, Drazba J, Vasanji A, Fantin A, Ruhrberg C, Buck M, Horowitz A. The cytoplasmic domain of neuropilin-1 regulates focal adhesion turnover. FEBS Lett 2013; 587: 3392-9.

80. Ballmer-Hofer K, Andersson AE, Ratcliffe LE, Berger P. Neuropilin-1 promotes VEGFR-2 trafficking through Rab11 vesicles thereby specifying signal output. Blood 2011; 118: 816-26.

81. Hirata T, Takagi S, Fujisawa H. The membrane protein A5, a putative neuronal recognition molecule, promotes neurite outgrowth. Neurosci Res 1993; 17: 159-69.

82. Pasterkamp RJ, Ruitenberg MJ, Verhaagen J. Semaphorins and their receptors in olfactory axon guidance. Cell Mol Biol (Noisyle-grand) 1999; 45: 763-79.

83. Tamagnone L, Comoglio PM. Signalling by semaphorin receptors: cell guidance and beyond. Trends Cell Biol 2000; 10: 377-83.

84. Chen H, Chedotal A, He Z, Goodman CS, Tessier-Lavigne M. Neuropilin-2, a novel member of the neuropilin family, is a high affinity receptor for the semaphorins Sema E and Sema IV but not Sema III. Neuron 1997; 19: 547-59.

85. Feiner L, Koppel AM, Kobayashi H, Raper JA. Secreted chick. semaphorins bind recombinant neuropilin with similar affinities but bind different subsets of neurons in situ. Neuron 1997; 19: 539-45.

86. Gu C, Rodriguez ER, Reimert DV, Shu T, Fritzsch B, Richards LJ, Kolodkin AL, Ginty DD. Neuropilin-1 conveys semaphorin and VEGF signaling during neural and cardiovascular development. Dev Cell 2003; 5: 45-57.

87. McLennan R, Kulesa PM. In vivo analysis reveals a critical role for neuropilin-1 in cranial neural crest cell migration in chick. Dev Biol 2007; 301: 227-39.

88. Chen H, Bagri A, Zupicich JA, Zou Y, Stoeckli E, Pleasure SJ, Lowenstein DH, Skarnes WC, Chédotal A, Tessier-Lavigne M. Neuropilin-2 regulates the development of selective cranial and sensory nerves and hippocampal mossy fiber projections. Neuron 2000; 25: 43-56.

89. Giger RJ, Cloutier JF, Sahay A, Prinjha RK, Levengood DV, Moore SE, Pickering S, Simmons D, Rastan S, Walsh FS, Kolodkin AL, Ginty DD, Geppert M. Neuropilin-2 is required in vivo for selective axon guidance responses to secreted semaphorins. Neuron 2000; 25: 29-41. 
90. Sahay A, Molliver ME, Ginty DD, Kolodkin AL. Semaphorin 3F is critical for development of limbic system circuitry and is required in neurons for selective CNS axon guidance events. J Neurosci 2003; 23: 6671-80.

91. Walz A, Rodriguez I, Mombaerts P. Aberrant sensory innervation of the olfactory bulb in neuropilin-2 mutant mice. J Neurosci 2002; 22: 4025-35.

92. Delgoffe GM, Woo SR, Turnis ME, Gravano DM, Guy C, Overacre $A E$, Bettini ML, Vogel P, Finkelstein D, Bonnevier J, Workman CJ, Vignali DA. Stability and function of regulatory T cells is maintained by a neuropilin-1-semaphorin-4a axis. Nature 2013; 501: 252-6.

93. Gu C, Yoshida Y, Livet J, Reimert DV, Mann F, Merte J, Henderson CE, Jessell TM, Kolodkin AL, Ginty DD. Semaphorin $3 \mathrm{E}$ and plexin-D1 control vascular pattern independently of neuropilins. Science 2005; 307: 265-8.

94. Barberis D, Artigiani S, Casazza A, Corso S, Giordano S, Love CA, Jones EY, Comoglio PM, Tamagnone L. Plexin signaling hampers integrin-based adhesion, leading to Rho-kinase independent cell rounding, and inhibiting lamellipodia extension and cell motility. FASEB J 2004; 18: 592-4.

95. Zanata SM, Hovatta I, Rohm B, Puschel AW. Antagonistic effects of Rnd1 and RhoD GTPases regulate receptor activity in Semaphorin 3A-induced cytoskeletal collapse. J Neurosci 2002; 22: 471-7.

96. Oinuma I, Ishikawa Y, Katoh H, Negishi M. The Semaphorin 4D receptor Plexin-B1 is a GTPase activating protein for R-Ras. Science 2004; 305: 862-5.

97. Komatsu M, Ruoslahti E. R-Ras is a global regulator of vascular regeneration that suppresses intimal hyperplasia and tumor angiogenesis. Nat Med 2005; 11: 1346-50.

98. Saito Y, Oinuma I, Fujimoto S, Negishi M. Plexin-B1 is a GTPase activating protein for M-Ras, remodelling dendrite morphology. EMBO Rep 2009; 10: 614-21.

99. Wang Y, He H, Srivastava N, Vikarunnessa S, Chen YB, Jiang J, Cowan CW, Zhang X. Plexins are GTPase-activating proteins for Rap and are activated by induced dimerization. Sci Signal 2012; 5: ra6.

100. Hung RJ, Terman JR. Extracellular inhibitors, repellents, and semaphorin/plexin/MICAL-mediated actin filament disassembly. Cytoskeleton (Hoboken) 2011; 68: 415-33.

101. Bagci T, Wu JK, Pfannl R, Ilag LL, Jay DG. Autocrine semaphorin $3 \mathrm{~A}$ signaling promotes glioblastoma dispersal. Oncogene 2009; 28: 3537-50.

102. Nasarre P, Constantin B, Rouhaud L, Harnois T, Raymond G, Drabkin HA, Bourmeyster N, Roche J. Semaphorin SEMA3F and VEGF have opposing effects on cell attachment and spreading. Neoplasia 2003; 5: 83-92.

103. Carmeliet P. Blood vessels and nerves: common signals, pathways and diseases. Nat Rev Genet 2003; 4: 710-20.

104. Sondell M, Lundborg G, Kanje M. Vascular endothelial growth factor has neurotrophic activity and stimulates axonal outgrowth, enhancing cell survival and Schwann cell proliferation in the peripheral nervous system. J Neurosci 1999; 19: 5731-40.

105. Erskine L, Reijntjes S, Pratt T, Denti L, Schwarz Q, Vieira JM, Alakakone B, Shewan D, Ruhrberg C. VEGF signaling through neuropilin 1 guides commissural axon crossing at the optic chiasm. Neuron 2011; 70: 951-65.

106. Shimizu A, Mammoto A, Italiano JE Jr, Pravda E, Dudley AC, Ingber DE, Klagsbrun M. ABL2/ARG tyrosine kinase mediates
SEMA3F-induced RhoA inactivation and cytoskeleton collapse in human glioma cells. J Biol Chem 2008; 283: 27230-8.

107. Serini G, Valdembri D, Zanivan S, Morterra G, Burkhardt C, Caccavari F, Zammataro L, Primo L, Tamagnone L, Logan M, Tessier-Lavigne M, Taniguchi M, Püschel AW, Bussolino F. Class 3 semaphorins control vascular morphogenesis by inhibiting integrin function. Nature 2003; 424: 391-7.

108. Tamagnone L, Mazzone M. Semaphorin signals on the road of endothelial tip cells. Dev Cell 2011; 21: 189-90.

109. Miao HQ, Soker S, Feiner L, Alonso JL, Raper JA, Klagsbrun M. Neuropilin-1 mediates collapsin-1/semaphorin III inhibition of endothelial cell motility: functional competition of collapsin-1 and vascular endothelial growth factor-165. J Cell Biol 1999; 146: $233-42$.

110. Narazaki M, Tosato G. Ligand-induced internalization selects use of common receptor neuropilin-1 by VEGF165 and semaphorin3A. Blood 2006; 107: 3892-901.

111. Guo HF, Li X, Parker MW, Waltenberger J, Becker PM, Vander Kooi CW. Mechanistic basis for the potent anti-angiogenic. activity of semaphorin 3F. Biochemistry 2013; 52: 7551-8.

112. Pan H, Wanami LS, Dissanayake TR, Bachelder RE. Autocrine semaphorin3A stimulates alpha2 beta1 integrin expression/ function in breast tumor cells. Breast Cancer Res Treat 2009; 118: 197-205.

113. Ellis LM. The role of neuropilins in cancer. Mol Cancer Ther 2006; 5: 1099-107.

114. Bagri A, Tessier-Lavigne M, Watts RJ. Neuropilins in tumor biology. Clin Cancer Res 2009; 15: 1860-4.

115. Ochiumi T, Kitadai Y, Tanaka S, Akagi M, Yoshihara M, Chayama K. Neuropilin-1 is involved in regulation of apoptosis and migration of human colon cancer. Int J Oncol 2006; 29: 105-16.

116. Samuel S, Gaur P, Fan F, Xia L, Gray MJ, Dallas NA, Bose D, Rodriguez-Aguayo C, Lopez-Berestein G, Plowman G, Bagri A, Sood AK, Ellis LM. Neuropilin-2 mediated $\beta$-catenin signaling and survival in human gastro-intestinal cancer cell lines. PLoS One 2011; 6: e23208.

117. Cai Y, Wang R, Zhao YF, Jia J, Sun ZJ, Chen XM. Expression of Neuropilin-2 in salivary adenoid cystic carcinoma: its implication in tumor progression and angiogenesis. Pathol Res Pract 2010; 206: 793-9.

118. Bender RJ, Mac Gabhann F. Expression of VEGF and semaphorin genes define subgroups of triple negative breast cancer. PLoS One 2013; 8: e61788.

119. Bachelder RE, Lipscomb EA, Lin X, Wendt MA, Chadborn NH, Eickholt BJ, Mercurio AM. Competing autocrine pathways involving alternative neuropilin-1 ligands regulate chemotaxis of carcinoma cells. Cancer Res 2003; 63: 5230-3.

120. Fukasawa M, Matsushita A, Korc M. Neuropilin-1 interacts with integrin beta 1 and modulates pancreatic cancer cell growth, survival and invasion. Cancer Biol Ther 2007; 6: 1173-80.

121. Goel HL, Pursell B, Standley C, Fogarty K, Mercurio AM. Neuropilin-2 regulates $\alpha 6 \beta 1$ integrin in the formation of focal adhesions and signaling. J Cell Sci 2012; 125: 497-506.

122. Cao Y, Hoeppner LH, Bach S, E G, Guo Y, Wang E, Wu J, Cowley MJ, Chang DK, Waddell N, Grimmond SM, Biankin AV, Daly RJ, Zhang X, Mukhopadhyay D. Neuropilin-2 promotes extravasation and metastasis by interacting with endothelial $\alpha 5$ integrin. Cancer Res 2013; 73: 4579-90.

123. Darbonne WC, Du X, Dhawan P, Hartley D, Tarrant J, Taylor H, Cain G, Shih LM, Brachmann RK, Phung Q, Weekes CD, 
LoRusso P, Patnaik A, Xiang H, Ramakrishnan V. Mechanism for platelet reduction in anti-neuropilin-1 (MNRP1685A)-treated phase I patients. J Clin Oncol 2011; 29: e13598.

124. Starzec A, Vassy R, Martin A, Lecouvey M, Di Benedetto M, Crepin M, Perret GY. Antiangiogenic and antitumor activities of peptide inhibiting the vascular endothelial growth factor binding to neuropilin-1. Life Sci 2006; 79: 2370-81.

125. von Wronski MA, Raju N, Pillai R, Bogdan NJ, Marinelli ER, Nanjappan P, Ramalingam K, Arunachalam T, Eaton S, Linder KE, Yan F, Pochon S, Tweedle MF, Nunn AD. Tuftsin binds neuropilin-1 through a sequence similar to that encoded by exon 8 of vascular endothelial growth factor. J Biol Chem 2006; 281: 5702-10.

126. Jarvis A, Allerston CK, Jia H, Herzog B, Garza-Garcia A, Winfield N, Ellard K, Aqil R, Lynch R, Chapman C, Hartzoulakis B, Nally J, Stewart M, Cheng L, Menon M, Tickner M, Djordjevic S, Driscoll PC, Zachary I, Selwood DL. Small molecule inhibitors of the neuropilin-1 vascular endothelial growth factor A (VEGF-A) interaction. J Med Chem 2010; 53: 2215-26.

127. Getz JA, Cheneval O, Craik DJ, Daugherty PS. Design of a cyclotide antagonist of neuropilin-1 and - 2 that potently inhibits endothelial cell migration. ACS Chem Biol 2013; 8: 1147-54.

128. Bachelder RE, Crago A, Chung J, Wendt MA, Shaw LM, Robinson $G$, Mercurio AM. Vascular endothelial growth factor is an autocrine survival factor for neuropilin-expressing breast carcinoma cells. Cancer Res 2001; 61: 5736-40.

129. Goel HL, Pursell B, Chang C, Shaw LM, Mao J, Simin K, Kumar P, Vander Kooi CW, Shultz LD, Greiner DL, Norum JH, Toftgard R, Kuperwasser C, Mercurio AM. GLI1 regulates a novel neuropilin-2/ $\alpha 6 \beta 1$ integrin based autocrine pathway that contributes to breast cancer initiation. EMBO Mol Med 2013; 5: 488-508.

130. von Wronski MA, Tweedle MF, Nunn AD. Binding of the C-terminal amino acids of VEGF121 directly with neuropilin-1 should be considered. FASEB J 2007; 21: 1292; author reply 3.

131. Teesalu T, Sugahara KN, Kotamraju VR, Ruoslahti E. C-end rule peptides mediate neuropilin-1-dependent cell, vascular, and tissue penetration. Proc Natl Acad Sci USA 2009; 106: 16157-62.

132. Delcombel R, Janssen L, Vassy R, Gammons M, Haddad O, Richard B, Letourneur D, Bates D, Hendricks C, Waltenberger J, Starzec A, Sounni NE, Noël A, Deroanne C, Lambert C, Colige A. New prospects in the roles of the C-terminal domains of VEGF-A and their cooperation for ligand binding, cellular signaling and vessels formation. Angiogenesis 2013; 16: 353-71.

133. Mac Gabhann F, Popel AS. Targeting neuropilin-1 to inhibit VEGF signaling in cancer: comparison of therapeutic approaches. PLoS Comput Biol 2006; 2: e180. 